\title{
Aerosol impacts on radiative and microphysical properties of clouds and precipitation formation
}

\author{
O. Alizadeh-Choobari ${ }^{\mathrm{a}, *}$, M. Gharaylou ${ }^{\mathrm{a}}$ \\ ${ }^{a}$ Institute of Geophysics, University of Tehran, Tehran, Iran
}

\begin{abstract}
Through modifying the number concentration and size of cloud droplets, aerosols have intricate impacts on radiative and microphysical properties of clouds, which together influence precipitation processes. Aerosol-cloud interactions for a mid-latitude convective cloud system are investigated using a two-moment aerosol-aware bulk microphysical scheme implemented into the Weather Research and Forecasting (WRF) model. Three sensitivity experiments with initial identical dynamic and thermodynamic conditions, but different cloud-nucleating aerosol concentrations were conducted. Increased aerosol number concentration has resulted in more numerous cloud droplets of overall smaller size, through which the optical properties of clouds have been changed. While the shortwave cloud forcing is significantly increased in more polluted experiments, changes in the aerosol number concentration have negligible impacts on the longwave cloud forcing. For the first time, it is found that polluted clouds have higher cloud base heights, the feature that is caused by more surface cooling due to a higher shortwave cloud forcing, as well as a drier boundary layer in the polluted experiment compared to
\end{abstract}

${ }^{*}$ Corresponding author. Institute of Geophysics, University of Tehran, Tehran, Iran.

Email address: omid.alizadeh@ut.ac.ir (O. Alizadeh-Choobari)

Preprint submitted to Atmospheric Research

(C) 2016. This manuscript version is made available under the Elsevier user license http://www.elsevier.com/open-access/userlicense/1.0/ 
the clean. The polluted experiment was also associated with a higher liquid water content (LWC) caused by an increase in the number of condensation of water vapor due to higher concentration of hygroscopic aerosols acting as condensation nuclei. The domain-averaged accumulated precipitation is little changed under both polluted and clean atmosphere. Nevertheless, changes in the rate of precipitation are identified, such that under polluted atmosphere light rain is reduced, while both moderate and heavy rain are intensified, confirming the fact that if an ample influx of water vapor exists, an increment of hygroscopic aerosols can increase the amount of precipitation.

Keywords: Aerosol-cloud interactions, Shortwave cloud forcing, Liquid water content, Cloud base height

1. Introduction

Atmospheric aerosols have intricate impacts on cloud microphysics by 3 modifying the number concentration and size of cloud droplets (Andreae 4 et al., 2004; Khain et al., 2004), which change the albedo of clouds (Twomey, 5 1977; Menon et al., 2002; Quaas et al., 2004; Fan et al., 2013), the coalescence 6 efficiency of droplets (Albrecht, 1989; Rosenfeld and Lensky, 1998; Rosenfeld 7 et al., 2001), the release of latent heat and the strength of cloud convection 8 (Andreae et al., 2004; Khain et al., 2004; Koren et al., 2005), the cloud top

feld and Lensky, 1998), the strength of the cold pool via changes in evaporation (Lebo, 2014; Lebo and Morrison, 2014; Grant and van den Heever, 2015) and consequently precipitation formation (Albrecht, 1989; Rosenfeld, 1999; Rosenfeld and Woodley, 2000; Khain et al., 2004; Zhang et al., 2005; 
Seifert and Beheng, 2006; Thompson and Eidhammer, 2014; Wang, 2015). All these changes are referred to as (or the result of) the aerosol indirect effects, which are considered one of the most uncertain forcing in climate (Zhang et al., 2015). The effects of aerosols on clouds include the "first indirect" or "Twomey" effect (Twomey, 1977) on cloud droplet size and thus reflectivity for a fixed liquid water content (LWC), and the "second indirect" effect (Ackerman et al., 2000) on lifetime and extent of clouds, as well as on precipitation processes (Zhang et al., 2005; Seifert and Beheng, 2006)

Twomey (1977) first stated that for a constant liquid water path, enhancement of aerosol concentration can increase the droplet concentration and decrease the mean size of cloud droplets, which increases the total droplet cross-sectional area, and consequently the cloud albedo, corresponding to the cooling of the climate system. Evidence of enhanced cloud reflectivity can be seen in clouds polluted by ship exhaust (Coakley et al., 1987), and in polluted continental compared to clean maritime clouds (Stefan and Iorga, 2004). However, it should be noted that the increase in cloud albedo in response to a decrease in droplet sizes is the greatest in shallow clouds because regardless of their droplet sizes, deep and water-rich clouds reflect most of the solar radiation (Platnick and Twomey, 1994).

The reduction of droplet sizes in polluted clouds inhibits collision and coalescence processes (Albrecht, 1989; Rosenfeld and Lensky, 1998; Rosenfeld et al., 2001); thereby slows the conversion of cloud droplets into rainfall, to the extent of completely suppressing warm-rain processes (Rosenfeld, 1999). The reduced warm-rain processes due to enhanced aerosols are evident in more precipitable shallow maritime clouds compared to their counterpart 
continental clouds (Ludlam, 1980; Mülmenstädt et al., 2015). This is also evident in the inverse relation identified between the droplet concentration and frequency of drizzle in stratocumulus clouds, both by observations (Albrecht et al., 1988; Rosenfeld et al., 2001) and simulations (Saleeby et al., 2015). The decreased rainfall in shallow clouds leads to an increase in the lifetime and coverage of clouds (Albrecht, 1989), to the extent that the resultant increase in the global albedo is believed to be much greater than the cloud albedo or "Twomey" effect (Sekiguchi et al., 2003; Kaufman et al., 2005).

Suppressing warm-rain processes delays the onset of precipitation (Andreae et al., 2004), such that in mixed-phase clouds enables the unprecipitated cloud droplets to reach greater heights, which results in more freezing of cloud droplets and the release of latent heat of freezing, higher cloud top heights, enhancement of cold-rain processes (Rosenfeld and Woodley, 2000; Li et al., 2011) and occasionally more intensive thunderstorms (Andreae et al., 2004). The greater release of latent heat prolongs the growth of convective clouds; thereby further invigorates the cloud development and formation of thunderstorms and large hails (Andreae et al., 2004; Rosenfeld, 2006) that eventually might affect the water cycle. In addition, an increase in the number of aerosol concentrations that can act as ice nuclei is associated with more frequent glaciation of supercooled clouds (referred to as the "glaciation indirect effect"), and an increase of precipitation via the ice phase (Lohmann and Lesins, 2002).

The aerosol indirect effects have been also extensively discussed in several recent observational-based studies. Using in situ measurements, Andreae 
et al. (2004) indicated a shift in the onset of precipitation to larger heights in smoky polluted clouds, which allows invigoration of updrafts and higher cloud tops, formation of large ice crystals, intense thunderstorms and large hails. They noted that microphysical effects of smoke aerosols on the development of clouds overcome on their radiative cooling effects which tend to suppress the boundary-layer clouds. Koren et al. (2005) found that an increase in the aerosol number concentration is associated with a delay in freezing (known as "thermodynamic effect") and an enhancement of cloud convection, which consequently leads to an increase in cloud coverage and the cloud top height. The increase of cloud convection in response to the increase of the aerosol number concentration was also found in a numerical study by Fan et al. (2007), although they noted that when the air is already heavily polluted, further increase of aerosols has less impact on convection processes. Using the Tropical Rainfall Measuring Mission (TRMM) precipitation measurements, Bell et al. (2008) found a significant increase in the summertime afternoon thunderstorms over the Southeastern United States, which was attributed to the mid-week increase in aerosol concentration.

Although the above discussed aerosol effects on cloud microphysics are well accepted, recent studies indicate that to fully understand such effects, environmental conditions such as humidity or convective available potential energy (CAPE) (Khain et al., 2008; Storer et al., 2010), wind shear (Fan et al., 2009; Lee et al., 2012; Lebo and Morrison, 2014) and the altitude of the dry layer (Grant and van den Heever, 2015) should be considered too. For example, it was found that an increase in aerosol concentration is associated with an increase in precipitation under tropical maritime conditions, 
but a decrease in precipitation for clouds developing under dry continental conditions (Khain et al., 2008). The decrease of precipitation in dry conditions was attributed to the sublimation of ice and evaporation of smaller drops when they are falling into a deep layer of dry air. Analysis of Fan et al. (2007) did not indicate such suppression effect, but they noted that the aerosol indirect effects are negligible in relatively dry air. Lebo and Morrison (2014) investigated the dynamical effects of increasing the aerosol loading on the strength and structure of squall lines. Their results indicated that under a weak wind shear, an increase in aerosol loading leads to the weakening of the cold pool, an intensification of the convective mass flux and an enhancement of precipitation, while the overall reduction of precipitation was found under a strong wind shear condition.

The explicit nucleation of cloud droplets and ice crystals by aerosols has been recently applied in the Weather Research and Forecasting (WRF) model. Li et al. (2008) first implemented a two-moment microphysics scheme with prognostic aerosol number and mass concentrations into the WRF model, and carried out simulations under different aerosol conditionss. They demonstrated that precipitation increases from clean marine to continental background conditions, but it is considerably reduced and completely suppressed under highly polluted cases. Suppression of precipitation at extremely high aerosol concentrations was attributed to the fact that ice production is minimal in such conditions; thus hydrometeors cannot grow to sufficiently large sizes to survive evaporation. Recently, Thompson and Eidhammer (2014) implemented a two-moment aerosol-aware bulk microphysical scheme into the WRF model to discuss the impacts of aerosols on clouds 
development and precipitation in a large winter cyclone. They found that aerosol effects on precipitation are much greater over the regions with light precipitation rates. They also noted a shift in the location of precipitation due to aerosol effects. More recently, Wang (2015) applied the cloud resolving WRF model with a modified Morrison two-moment bulk microphysical scheme. He identified an intensified convection and more efficient mixedphase processes under a polluted aerosol condition.

In spite of the existing knowledge, it is not yet clear how spatial distribution and the rate of precipitation changes in response to the combined effects of aerosols on radiative and microphysical properties of clouds. Here it has been shown that the aerosol effect on precipitation processes is a function of precipitation intensity, such that light rain has been reduced or completely suppressed under the polluted atmosphere, while moderate and heavy rainfall have been intensified.

The main objective of the present study is to investigate if and to the extent that the following features are related to the aerosol indirect effects: (1) the optical properties of clouds; (2) the cloud base height; (3) total accumulated precipitation; and (4) the rate of precipitation. To this end, a twomoment aerosol-aware bulk microphysical scheme, developed by Thompson and Eidhammer (2014), is applied.

\section{Model description}

\subsection{The WRF model}

The WRF mesoscale model version 3.7 (Janjic et al., 2003) was applied to investigate responses of cloud properties to changes in aerosol concentration. 


\subsection{Two-moment aerosol-aware bulk microphysical scheme}

A two-moment aerosol-aware bulk microphysical scheme, developed and discussed by Thompson and Eidhammer (2014), is used in the present study. This is an update of Thompson et al. (2008) bulk microphysical scheme which explicitly incorporates nucleation of cloud droplets and ice crystals. In the two-moment bulk microphysical schemes, both the mass and total number concentration of cloud droplets are predicted, while one-moment microphysical schemes only consider the mass concentration of hydrometeors. The Thompson aerosol-aware scheme calculates the mass mixing ratio of water vapor, cloud droplets, rain drops, ice crystals, snow, and graupel, as well as the number concentration of cloud droplets, ice crystals and rain drops. The Köhler activation theory (Köhler, 1936) is used for nucleation of aerosols to form cloud droplets, and a generalized gamma distribution is assumed for cloud droplets.

Ice nucleation is based on the number concentration of mineral dust aerosols as dust is the most abundant natural ice nuclei in the atmosphere (Hoose et al., 2010; Murray et al., 2012), while other ice nuclei are not incorporated in the current version of the WRF model. Nucleation of dust particles into ice crystals is based on the parameterization of DeMott et al. (2010) for condensation and immersion freezing at relative humidity above water saturation and the parameterization of Phillips et al. (2008) for deposition nucleation at relative humidity less than water saturation. More descriptions of the two-moment aerosol-aware bulk microphysical scheme, and the approach adopted for nucleation of cloud droplets and ice crystals can be found in Thompson and Eidhammer (2014). 


\subsection{Input aerosol dataset}

The initial aerosol number concentrations were obtained from 7-yr (20012007) global simulations (Colarco et al., 2010) of the Goddard Chemistry Aerosol Radiation and Transport (GOCART) model (Ginoux et al., 2001) with $0.5^{\circ}$ longitude by $1.25^{\circ}$ latitude resolution. The aerosol input data include mass mixing ratios of sulfate, dust, black carbon (BC), organic carbon (OC), and sea salt, although black carbon is ignored in the cloud condensation nuclei (CCN) activation. As noted by Thompson and Eidhammer (2014), dust aerosols larger than $0.5 \mu \mathrm{m}$ are accumulated into the ice-nucleating mode, while all other aerosol species are combined into the cloud-droplet-nucleating mode. By assuming lognormal distributions and applying the approach of Chin et al. (2002) for characteristic diameters and geometric standard deviations, the input mass mixing ratios were converted to number concentrations. For simplicity, a variable lower boundary condition was implemented to represent surface aerosol emissions based on the initial near-surface aerosol concentration and mean surface wind. The following formula then has been applied in lowest level of the model to calculate the flux of aerosols: $\mathrm{dN}_{w f a} / \mathrm{dt}=10^{\left[\log \left(N_{w f a}\right)-3.69897\right]}$, where $\mathrm{N}_{w f a}$ denotes hygroscopic aerosol number concentration. More descriptions are presented in Thompson and Eidhammer (2014).

\subsection{Numerical experiments}

Three sensitivity experiments with different initial and boundary hygroscopic aerosol number concentrations were conducted for an observed case of convective cloud development and rainfall over Tehran on April 14, 2012. The aim is to investigate the response of cloud properties to changes in aerosol 
number concentrations, while the number of non-hygroscopic ice-nucleating aerosol concentrations (that has been considered to be dust) was remained identical for the three experiments. Hygroscopicity parameter was assumed to be 0.4 , while aerosol mean radius considered to be $0.04 \mu \mathrm{m}$, although they can be both altered to represent different aerosol populations. The aerosol number concentration in the first simulation represents conditions of the current era, and this simulation is referred to as the control experiment. In the second simulation, hygroscopic aerosol number concentration was reduced to one-fifth of the control experiment, and it is referred to as the clean experiment. Finally, to investigate the impacts of high aerosol concentration on cloud microphysics and precipitation, the aerosol number concentration at all model grid points was increased by a factor of 5 , and this simulation is referred to as the polluted experiment. As shown in Table 1, the innermost domain-averaged hygroscopic aerosol number concentrations averaged over the simulation period and in all vertical levels were 109.8, 509.1 and 2656.6 $\mathrm{cm}^{-3}$ in the clean, control and polluted experiments, respectively. Spatial distribution of initial hygroscopic aerosol number concentration at the surface in the control simulation is also shown in Figure 1, while vertical profiles of initial domain-averaged hygroscopic and ice-friendly aerosol number concentrations for the three experiments are depicted in Figure 2. Apart from differences in the initial and boundary hygroscopic aerosol number concentrations, the model setups and meteorological initial and boundary conditions for the three experiments are identical.

Simulations were configured with a mother domain and two two-way interactive nested domains (nesting ratios: 1:3:3), using $120 \times 120,121 \times$ 
100 and $151 \times 121$ horizontal grid points, respectively. The WRF domain configuration is shown in Figure 1, while topographic features of Iran are overlapped. In the vertical, $45 \sigma$-levels up to $50 \mathrm{hPa}$ were used, spaced from $68 \mathrm{~m}$ near the surface to $500 \mathrm{~m}$ near the midtroposphere. The mother domain was configured with the horizontal resolution of $21000 \mathrm{~m}$, while the nested domains were configured to have horizontal resolutions of 7000 and $2333 \mathrm{~m}$, respectively. Simulations were conducted for 30 hours, starting at 1800 UTC 13 April 2012. To minimize the impact from the initial conditions, only results from 0000 UTC 14 to 0000 UTC 15 April (referred to as the simulation period hereafter) are analyzed. The meteorological initial and lateral boundary conditions were derived from the National Center for Environmental Prediction final analysis (NCEP/FNL) data at $1^{\circ}$ horizontal resolution and $6 \mathrm{~h}$ temporal intervals.

The geographical data for the land-use and topography were obtained from the standard USGS (United States Geological Survey) dataset, with the resolution of 30 -arc second $(0.9 \mathrm{~km})$ for the innermost domain. The model physics that have been applied in the experiments are as follows. Convection processes for the mother and first nested domains were parameterized using Kain-Fritsch scheme (Kain, 2004), while modeled explicitly in the innermost domain. Dudhia (Dudhia, 1989) and Rapid Radiative Transfer Model (RRTM; Mlawer et al., 1997) were used for shortwave and longwave radiation, respectively. Five layer thermal diffusion land-surface scheme and the revised MM5 similarity theory surface layer scheme (Jiménez et al., 2012) were used. This revised version removes previously identified limits, and uses updated stability functions. Boundary-layer processes were parameter- 
ized using the non-local Yonsei University (YSU) scheme, with an explicit entrainment layer and a parabolic K profile in an unstable mixed layer (Hong et al., 2006).

\section{Model evaluation}

Accumulated rainfall from the state-of-the-art WRF model for the control experiment is compared against the TRMM product (3B42 V7) with the $0.25^{\circ}$ $\times 0.25^{\circ}$ resolution (Figure 3a-b). The WRF model correctly represented the rainfall occurrence in the northern half of Iran. However, the model overestimated the accumulated rainfall over the complex topographic regions.

Vertical profiles of air temperature and wind speed simulated at 0000 UTC 14 April 2012 are also compared against the corresponding atmospheric radiosondes at a synoptic station located at $35.7^{\circ} \mathrm{N}, 51.3^{\circ} \mathrm{E}$ and $1190.8 \mathrm{~m}$ above mean sea level (Figure 3c-d). Apart from layers very close to the surface, the vertical profile of air temperature simulated by the model agrees very well with the radiosonde profile. However, a temperature inversion near the surface that is simulated at 0000 UTC was not observed. The vertical profile of the observed wind speed is also well simulated by the model, including the observed maximum wind speed located between 600 and 500 hPa.

\section{Synoptic overview}

The pattern of the convective system triggered by a mid-level trough forcing is shown in Figure 4. It is clear that the arrival of a cooler air from the north and the mid-level trough from the southwest of Tehran invigorates 
pre-existing convective processes, which are typical in the early spring season. At 0000 UTC 14 April 2012, the trough appeared at both 500 and $300 \mathrm{hPa}$ in southwest of Iran, while a ridge was dominated in the east parts. At this time, a closed low was formed at $500 \mathrm{hPa}$ in north of the Persian Gulf, and a strong jet stream at $300 \mathrm{hPa}$ was extended from eastern Turkey through Iraq to the southern Persian Gulf. This mid-level trough was associated with a tongue of surface low pressure on the border of Iran and Iraq, with the value of $1008 \mathrm{hPa}$. Twelve hours later, the low-pressure at $500 \mathrm{hPa}$ was weakened and moved a bit to the east, while the jet at $300 \mathrm{hPa}$ was intensified. At the surface, a closed low pressure was formed, with the center of $1008 \mathrm{hPa}$. At 0000 UTC 15 April 2012, the 500-hPa trough moved further eastward by the westerlies, and the $300-\mathrm{hPa}$ jet was significantly weakened. As a consequence of the influence of this convective system, a total rainfall of 14.4 mm was reported at Tehran Mehrabad airport synoptic station from 0000 UTC 14 April to 0000 UTC 15 April 2012.

\section{Results}

\subsection{Changes in the number and size of cloud droplets}

Microphysical properties of clouds are analyzed under different hygroscopic aerosol number concentrations to understand the effects of aerosols on clouds development and precipitation processes. Aerosol number concentrations averaged over the innermost domain and in all vertical levels for the three experiments are presented in Table 1 . They include $105.5 \mathrm{~cm}^{-3}$ in the clean, $574.7 \mathrm{~cm}^{-3}$ in the control and $2670.8 \mathrm{~cm}^{-3}$ in the polluted experiments. Changes in the initial and boundary hygroscopic aerosol number concentra- 
tions were associated with significant changes in the number concentrations of cloud droplets. On average, the number concentrations of cloud droplets in cloudy grid points of the innermost domain were found to be 45.9, 158.3 and $416.5 \mathrm{~cm}^{-3}$ in the clean, control and polluted experiments, respectively. This indicates that an increase in the number of hygroscopic aerosol concentrations was associated with more activation of aerosols to form cloud droplets, consistent with previous observations (e.g. Andreae et al., 2004) and numerical studies (e.g. Fan et al., 2007; Li et al., 2008). Reduction of supersaturation is expected when a larger number of cloud droplets are competing for a fixed amount of available water vapor. With the increase in the number of hygroscopic aerosol concentrations, the mean cloud droplet size has been decreased. The mean effective radii of cloud droplets in cloudy grid points of the innermost domain averaged during the simulation period have been $8.53,6.10$ and $5.22 \mu \mathrm{m}$ for the clean, control and polluted experiments, respectively, confirming the reduction in the mean size of cloud droplets with an increase in aerosol loading.

\subsection{Changes in cloud radiative forcing}

An increase in the number concentration, but a decrease in the mean size of cloud droplets in the polluted experiment is associated with an increase in the total droplet cross-sectional area, and consequently the shortwave cloud forcing, as shown in Figure 5 and Table 2, which is expected according to the "Twomey" effect. In the polluted experiment, reflection of solar radiation back to space by clouds is increased by $4.8 \%\left(5.1 \mathrm{~W} \mathrm{~m}^{-2}\right)$ in the innermost domain, implying that the first indirect effect of aerosols plays a major role in the atmospheric energy budget. In contrary, the shortwave cloud forcing 
is decreased by $10.5 \%\left(11.1 \mathrm{~W} \mathrm{~m}^{-2}\right)$ in the clean compared to the control experiment. Higher reflection of solar radiation in the polluted experiment is also clearly evident in Figure 5, which is attributed to the discussed changes in the mean size of cloud droplets. The obtained values of shortwave cloud forcing are comparable to the previous estimates. For example, observational analysis by Kaufman et al. (2005) indicated that on the global scale combination of aerosol-cloud albedo and lifetime effects are associated with the forcing of $-11 \pm 3 \mathrm{~W} \mathrm{~m}^{-2}$.

In contrast to the impacts on shortwave radiation, cloud forcing on longwave radiation at the top of the atmosphere (TOA) is positive because clouds block longwave radiation emitted to space from the Earth's surface. Nevertheless, as Table 2 indicates, in all experiments, the positive longwave cloud forcing is nearly half of the negative shortwave cloud forcing, suggesting that clouds have an overall cooling effect on the climate system. Nearly similar simulated values of the longwave cloud forcing in the three experiments suggest that changes in the $\mathrm{CCN}$ concentration have little effect on the longwave radiation, as previously noted by Albrecht (1989).

The identified net (shortwave + longwave) cooling effect when hygroscopic aerosols are more abundant can lead to the stabilization of the daytime boundary layer, which can weaken or suppress formation of convective clouds. This thermodynamic impact is in addition to the radiative and microphysical impacts of aerosols on cloud and precipitation processes, although changes in cloud microphysics by aerosols have dynamical and thermodynamical consequences too. 


\subsection{Other effects of aerosols on cloud properties}

Comparisons of the three conducted experiments indicate that cloud base heights increase with the increase in the number of hygroscopic aerosol concentrations, such that the innermost domain- and time-averaged cloud bases are found approximately at 1710.7, 1745.9 and $1773.3 \mathrm{~m}$ above the surface for the clean, control and polluted experiments, respectively (Table 2). It should be noted that the obtained cloud base heights in the three experiments show only small differences, confirming the fact that variations in aerosol concentrations have little impact on cloud development compared to the changes in environmental conditions (e.g. see Grant and van den Heever, 2015). The increase of the cloud base height in the polluted experiment can be related to the identified higher shortwave cloud forcing, which resulted in more cooling effect at the surface. As a results, surface convection processes are weakened, which caused simulation of a drier boundary layer in the polluted experiment compared to the clean. Indeed, our analysis indicates that throughout the day, near-surface air temperature is lower in the polluted experiment compared to the other two experiments, while a drier boundary layer is also simulated (not shown). It should be mentioned that the small differences in the cloud base heights of the three experiments could be also affected by the coarse vertical resolution of the model.

Figure 6 compares vertical profiles of mass concentrations of some hydrometeors under the clean, control and polluted aerosol conditions averaged during the simulation period. The mass content of cloud droplets is the highest in the polluted experiment because in response to higher concentrations of aerosols, more aerosols are activated into cloud droplets; thus more 
condensation of water vapor is occurred (Figure 6a). In other words, as the number of hygroscopic aerosols is greater in the polluted experiment, more water vapor has the chance to condense on aerosols and form cloud droplets. On the other hand, the lowest content of cloud droplets is found in the clean experiment, which is caused by less available aerosols to activate into cloud droplets. In spite of the discussed differences in the mass concentration, the height of the maximum cloud droplets content is nearly the same in the three experiments because condensation of water vapor occurs mainly below the freezing level, as previously stated by Li et al. (2008).

The discussed changes in the number of cloud droplets influence condensation and efficiency of the autoconversion process from cloud droplets to rain drops, such that overall, the rain drops content attains the greatest amount in the clean experiment (Figure 6b). Less overall contents of rain drops in the control and polluted experiments compared to the clean are due to the fact that the effective radii of cloud droplets are reduced in more polluted experiments (see Table 1); thus conversion of cloud droplets to rain drops are hindered.

Figure $6 \mathrm{c}$ indicates that time-averaged ice production is maximum in the clean experiment. As Pruppacher and Klett (1997) argued, this could be due to the fact that immersion freezing increases with the formation of larger droplets in the low CCN case. However, contribution of immersion freezing in producing different ice production in the three experiments cannot be examined in the present study because based on Thompson and Eidhammer (2014), condensation and immersion nucleation are grouped into a single function following DeMott et al. (2010). Some other factors might have also 
contributed. As previously discussed by Khain et al. (2001), clean clouds produce larger droplets which lead to rapid freezing at warmer temperatures. It is not then surprising that the ice production in the lower atmosphere is simulated to be the highest in the clean experiment. In spite of more mass concentration of ice crystals, the clean experiment corresponds to the least snow formation (Figure 6d), reflecting less conversion of ice to snow due to a smaller number of ice crystals. The polluted experiment, on the other hand, corresponds to the maximum snow formation. Overall, comparisons of rain drops and snow contents in the polluted and clean experiments indicate that polluted clouds produce more snow (due to more efficient mixed-phase processes), but less rain (due to suppression of warm-rain processes) compared to clean clouds. In fact, as polluted clouds produce less rain, more water vapor is left to ascend from lower levels to the mid and upper troposphere (Teller and Levin, 2006), causing more snow to form.

To better understand the impacts of aerosols on cloud microphysics, vertical cross sections through the most cloudy region for the number concentrations of cloud droplets, rain drops and ice crystals for the clean, control and polluted experiments at 0400 UTC 14 April 2012 are presented in Figure 7. Due to more available CCN, significantly higher cloud droplet number concentration is found in the polluted experiment compared to the other two experiments (Figure 7a-c). The least cloud droplet number concentration is simulated for the clean experiment, which is caused primarily by the lack of aerosol particles for the supercooled water to condense. Cloud droplets also reach to greater heights in the polluted experiment, simply because droplets are smaller in the polluted experiment; thus typically freeze at lower temper- 
atures (higher in the cloud).

In contrast to the number concentration of cloud droplets, the number concentration of rain drops is the highest in the clean experiment, while the least is simulated for the control experiment (Figure $7 \mathrm{~d}-\mathrm{f}$ ). This implies that as cloud droplets are larger in the clean experiment (see Table 1), their conversion into rain drops is more efficient. In all experiments, ice crystals are primarily distributed above the 7-km level (Figure 7g-i). However, on average, due to the lowest number of rain drops, the number concentration of ice crystals is the highest in the control experiment. Suppression of warm rain results in fewer rain drops and thus more cloud droplets that are lofted into the colder regions of the cloud, allowing for the formation of more ice.

Vertical cross sections of the mass concentrations of hydrometeors at 0400 UTC 14 April 2012 are also shown in Figure 8. Due to more droplet condensation, the highest mass content of cloud droplets is simulated in the polluted experiment (Figure 8a-c), consistent with previous observations (Rosenfeld and Woodley, 2000; Kaufman and Koren, 2006) and numerical simulations (Fan et al., 2007) in cumulus clouds. On the contrary, on average the greatest mass of rain drops is found for the clean experiment (Figure 8d-f), which combined with the identified less cloud droplets, suggest that conversion from cloud droplets to rain drops is more efficient in the clean experiment. The highest concentration of ice crystals at this particular time is found for the polluted case (Figure 8g-i), suggesting a hindered warm rain process, but enhanced mixed-phase processes because of a greater number of elevated aerosols.

Time-averaged liquid water contents, cloud fractions and surface rainfall 
in the three experiments are depicted in Figure 9. In earlier studies, LWC was assumed to be constant as aerosol concentration underwent a change (Twomey et al., 1984). However, as evidenced by the results of the present study (Figure 9), and was first noted by Charlson et al. (1987), LWC varies with CCN concentrations. For example, an increase in LWC was identified in the ship tracks compared to the surrounding environment (Ferek et al., 2000). Figure 9 and Table 2 clearly indicate that a decrease in the number of $\mathrm{CCN}$ in the clean experiment is associated with a significant reduction in LWC. This is expected because when few aerosol particles activate, the result is few but relatively large drops, which results in a relatively low bulk condensation rate relative to a situation in which there are numerous small droplets. Similarly, a decrease in CCN concentrations resulted in an overall decrease in cloud fraction in the clean experiment (see Table 2 and Figure $9)$.

\subsection{Precipitation response to aerosols}

Distributions of accumulated surface precipitation in the three experiments are also depicted in Figure 9. Although Table 1 indicates that the domain-averaged accumulated precipitation in the three experiments have little changed (with the highest amount in the clean experiment), significant changes in the amount of accumulated precipitation in different regions are detectable in Figure 9. Locally, both increase and decrease in surface precipitation in response to changes in the number of aerosol concentration are evident, similar to the results of Thompson and Eidhammer (2014). Nearly in the center of the domain where the highest accumulated precipitation is simulated in the three experiments, rainfall has been much stronger in the 
polluted experiment.

To better examine precipitation response to the number of aerosols, rainfall is categorized into three classes based on its intensity: light $(<0.6 \mathrm{~mm}$ $\left.\mathrm{hr}^{-1}\right)$, moderate $\left(0.6-1 \mathrm{~mm} \mathrm{hr}^{-1}\right)$ and heavy $\left(>=1 \mathrm{~mm} \mathrm{hr}^{-1}\right)$ rain. Figure 10 compares the percentage of precipitation amount for the three categories in the clean and polluted experiments. It is evident that in the polluted atmosphere, light rainfall is weakened, while moderate to heavy rainfall is intensified. This implies that over the areas with an ample influx of water vapor, an increment of hygroscopic aerosols can increase the amount of precipitation. On the other hand, over the areas with insufficient amounts of water vapor, droplets have to compete for water vapor in order to grow; thus further increment of hygroscopic aerosols reduce the precipitation amount. The decrease of light rainfall, and the increase of moderate to heavy rainfall in polluted clouds, i.e. shifting the rain distribution from light to heavy under more polluted conditions, was also previously observed (e.g., Qian et al., 2009; Li et al., 2011).

\section{Conclusions}

Computationally efficient two-moment aerosol-aware bulk microphysical scheme developed and implemented into the WRF model by Thompson and Eidhammer (2014) is used to investigate the impacts of aerosols on cloud properties and precipitation. Three sensitivity experiments with different hygroscopic aerosol number concentrations were conducted: the control, clean and polluted experiments. The aerosol number concentration represents the current era conditions for the control experiment, while it is reduced to one- 
fifth and increased by a factor of 5 in the clean and polluted experiments, respectively.

The impacts of changing the aerosol number concentrations on shortwave and longwave cloud forcing were investigated. In the polluted experiment, more numerous cloud droplets of overall smaller size was identified, while the reverse was true for the clean experiment. As a consequence, it was found that an increase in the number of $\mathrm{CCN}$ in the polluted experiment was associated with an increase in the amount of solar radiation reflected back to space, while a little impact on the longwave radiation was identified. The higher reflection of shortwave radiation by polluted clouds implies that they have more cooling effect on the Earth-atmosphere system. This daytime cooling aerosol first indirect effect partly compensates the greenhouse warming, suggesting that less surface warming trend in the daytime compared to nighttime in urban areas (Karl et al., 1984; Argüeso et al., 2014; Alizadeh-Choobari et al., 2016) could be partly due to the aerosol-cloud radiative effects. Due to a larger mean droplet size and less LWC, the least shortwave cloud forcing was simulated in the clean experiment.

For the first time, it was found that the cloud base height responses to the aerosol number concentrations, such that a higher cloud base height was found under a polluted atmosphere. The identified higher cloud base height in polluted clouds is caused by more surface cooling and a drier boundary layer compared to clean clouds. In addition, decreases in LWC and cloud fraction were identified in the clean experiment, while they were both increased in the polluted experiment. The lower LWC in the clean experiment was caused by less condensation of water vapor due to lower concentration of 
hygroscopic aerosols. The increased LWC in the polluted experiment which has been identified in the present study is in contrast to the results of Twomey (1977) who assumed a constant LWC, but is similar to the results of Albrecht (1989).

The impacts of changing the aerosol number concentrations on total precipitation were examined. Although the domain-averaged accumulated precipitation was little changed under both polluted and clean experiments, noticeable changes in the spatial distribution and rate of precipitation were identified. Generally, under polluted atmosphere light rain is reduced, while moderate and heavy rain are both intensified, and the heaviest precipitation changes the most. Our results for a convective cloud system in spring are in contrast to the results of Thompson and Eidhammer (2014) who found that for a cloud system driven by a frontal system in winter, the lightest amount of precipitation changes the most. This implies that the response of precipitation to aerosol loading strongly depends on the fact that whether the region is influenced by a frontal system or a convective cloud system.

\section{Acknowledgement}

The authors would like to thank Gregory Thompson at NCAR for helping to use the Thompson aerosol-aware scheme. This work has been financially supported by Iran National Science Foundation (INSF).

\section{References}

Ackerman, A. S., Toon, O. B., Stevens, D. E., Heymsfield, A. J., Ramanathan, V., Welton, E. J., 2000. Reduction of 
tropical cloudiness by soot. Science 288 (5468), 1042-1047. http://dx.doi.org/10.1126/science.288.5468.1042.

Albrecht, B. A., 1989. Aerosols, cloud microphysics, and fractional cloudiness. Science $245 \quad$ (4923), 1227-1230. http://dx.doi.org/10.1126/science.245.4923.1227.

Albrecht, B. A., Randall, D. A., Nicholls, S., 1988. Observations of marine stratocumulus clouds during fire. Bull. Amer. Meteorol. Soc. 69 (6), 618626.

Alizadeh-Choobari, O., Ghafarian, P., Adibi, P., 2016. Inter-annual variations and trends of the urban warming in Tehran. Atmos. Res. 170, 176185. http://dx.doi.org/10.1016/j.atmosres.2015.12.001.

Andreae, M. O., Rosenfeld, D., Artaxo, P., Costa, A. A., Frank, G. P., Longo, K. M., Silva-Dias, M. A. F., 2004. Smoking rain clouds over the Amazon. Science 303 (5662), 1337-1342. http://dx.doi.org/10.1126/science.1092779

Argüeso, D., Evans, J. P., Fita, L., Bormann, K. J., 2014. Temperature response to future urbanization and climate change. Clim. Dyn. 42 (7), 2183-2199. http://dx.doi.org/10.1007/s00382-013-1789-6.

Bell, T. L., Rosenfeld, D., Kim, K.-M., Yoo, J.-M., Lee, M.-I., Hahnenberger, M., 2008. Midweek increase in U.S. summer rain and storm heights suggests air pollution invigorates rainstorms. J. Geophys. Res. 113, D02209. http://dx.doi.org/10.1029/2007JD008623. 
Charlson, R. J., Lovelock, J. E., Andreae, M. O., Warren, S. G., 1987. Oceanic phytoplankton, atmospheric sulphur, cloud albedo and climate. Nature 326 (6114), 655-661. http://dx.doi.org/10.1038/326655a0.

Chin, M., Ginoux, P., Kinne, S., Torres, O., Holben, B. N., Duncan, B. N., Martin, R. V., Logan, J. A., Higurashi, A., Nakajima, T., 2002. Tropospheric aerosol optical thickness from the GOCART model and comparisons with satellite and sun photometer measurements. J. Atmos. Sci. $59(3), 461-483$.

Coakley, J. A., Bernstein, R. L., Durkee, P. A., 1987. Effect of shipstack effluents on cloud reflectivity. Science 237 (4818), 1020-1022. http://dx.doi.org/10.1126/science.237.4818.1020.

Colarco, P., Silva, A. d., Chin, M., Diehl, T., 2010. Online simulations of global aerosol distributions in the NASA GEOS-4 model and comparisons to satellite and ground-based aerosol optical depth. J. Geophys. Res. 115, D14207. http://dx.doi.org/10.1029/2009JD012820.

DeMott, P. J., Prenni, A. J., Liu, X., Kreidenweis, S. M., Petters, M. D., Twohy, C. H., Richardson, M. S., Eidhammer, T., Rogers, D. C., Tolbert, M. A., 2010. Predicting global atmospheric ice nuclei distributions and their impacts on climate. Proc. Natl. Acad. Sci. USA 107 (25), $11217-$ 11222. http://dx.doi.org/10.1073/pnas.0910818107.

Dudhia, J., 1989. Numerical study of convection observed during the winter monsoon experiment using a mesoscale two-dimensional model. J. Atmos. Sci. 46 (20), 3077-3107. 
Fan, J., Leung, L. R., Rosenfeld, D., Chen, Q., Li, Z., Zhang, J., Yan, H., 2013. Microphysical effects determine macrophysical response for aerosol impacts on deep convective clouds. Proc. Natl. Acad. Sci. USA 110 (48), E4581-E4590. http://dx.doi.org/10.1073/pnas.1316830110.

Fan, J., Yuan, T., Comstock, J. M., Ghan, S., Khain, A., Leung, L. R., Li, Z., Martins, V. J., Ovchinnikov, M., 2009. Dominant role by vertical wind shear in regulating aerosol effects on deep convective clouds. J. Geophys. Res. 114, D22206. http://dx.doi.org/10.1029/2009JD012352.

Fan, J., Zhang, R., Li, G., Tao, W.-K., 2007. Effects of aerosols and relative humidity on cumulus clouds. J. Geophys. Res. 112, D14204. http://dx.doi.org/10.1029/2006JD008136.

Ferek, R. J., Garrett, T., Hobbs, P. V., Strader, S., 2000. Drizzle suppression in ship tracks. J. Atmos. Sci. 57 (16), 2707-2728.

Ginoux, P., Chin, M., Tegen, I., Prospero, J. M., Holben, B., Dubovik, O., Lin, S. J., 2001. Sources and distributions of dust aerosols simulated with the GOCART model. J. Geophys. Res. 106 (D17), 20255-20273. http://dx.doi.org/10.1029/2000JD000053.

Grant, L. D., van den Heever, S. C., 2015. Cold pool and precipitation responses to aerosol loading: Modulation by dry layers. J. Atmos. Sci. 72, 1398-1408. http://dx.doi.org/10.1175/JAS-D-14-0260.1

Hong, S. Y., Noh, Y., Dudhia, J., 2006. A new vertical diffusion package with an explicit treatment of entrainment processes. Mon. Weather Rev. 134 (9), 2318-2341. 
Hoose, C., Kristjánsson, J. E., Burrows, S. M., 2010. How important is biological ice nucleation in clouds on a global scale? Environ. Res. Lett. 5, 024009 .

Janjic, Z., Black, T., Rogers, E., Chuang, H., DiMego, G., 2003. The NCEP nonhydrostatic mesoscale forecasting model. In: 10th Conference on Mesoscale Processes. Portland, OR, Amer. Meteor. Soc., online.

Jiménez, P. A., Dudhia, J., González-Rouco, J. F., Navarro, J., Montávez, J. P., García-Bustamante, E., 2012. A revised scheme for the WRF surface layer formulation. Mon. Weather Rev. 140 (3), 898-918.

Kain, J. S., 2004. The Kain-Fritsch convective parameterization: An update. J. Appl. Meteorol. 43 (1), 170-181.

Karl, T. R., Kukla, G., Gavin, J., 1984. Decreasing diurnal temperature range in the United States and Canada from 1941 through 1980. J. Clim. Appl. Meteor. 23 (11), 1489-1504.

Kaufman, Y. J., Koren, I., 2006. Smoke and pollution aerosol effect on cloud cover. Science 313 (5787), 655-658. http://dx.doi.org/10.1126/science.1126232.

Kaufman, Y. J., Koren, I., Remer, L. A., Rosenfeld, D., Rudich, Y., 2005. Smoke, dust and pollution aerosol clouding the Atlantic atmosphere. Proc. Natl. Acad. Sci. USA 102, 11207-11212. http://dx.doi.org/10.1073/pnas.0505191102.

Khain, A., Pokrovsky, A., Pinsky, M., Seifert, A., Phillips, V., 2004. Simulation of effects of atmospheric aerosols on deep turbulent convective clouds 
using a spectral microphysics mixed-phase cumulus cloud model. Part I: Model description and possible applications. J. Atmos. Sci. 61 (24), 29632982 .

Khain, A. P., BenMoshe, N., Pokrovsky, A., 2008. Factors determining the impact of aerosols on surface precipitation from clouds: An attempt at classification. J. Atmos. Sci. 65 (6), 1721-1748.

Khain, A. P., Rosenfeld, D., Pokrovsky, A., 2001. Simulating convective clouds with sustained supercooled liquid water down to $-37.5^{\circ} \mathrm{C}$ using a spectral microphysics model. Geophys. Res. Lett. 28 (20), 3887-3890. http://dx.doi.org/10.1029/2000GL012662.

Köhler, H., 1936. The nucleus in and the growth of hygroscopic droplets. Trans. Faraday Soc. 32, 1152.

Koren, I., Kaufman, Y. J., Rosenfeld, D., Remer, L. A., Rudich, Y., 2005. Aerosol invigoration and restructuring of Atlantic convective clouds. Geophys. Res. Lett. 32, L14828. http://dx.doi.org/10.1029/2005GL023187.

Lebo, Z. J., 2014. The sensitivity of a numerically simulated idealized squall line to the vertical distribution of aerosols. J. Atmos. Sci. 71 (12), 45814596.

Lebo, Z. J., Morrison, H., 2014. Dynamical effects of aerosol perturbations on simulated idealized squall lines. Mon. Weather Rev. 142 (3), 991-1009. http://dx.doi.org/10.1175/MWR-D-13-00156.1 
Lee, S.-S., Feingold, G., Chuang, P. Y., 2012. Effect of aerosol on cloudenvironment interactions in trade cumulus. J. Atmos. Sci. 69 (12), 36073632 .

Li, G., Wang, Y., Zhang, R., 2008. Implementation of a twomoment bulk microphysics scheme to the WRF model to investigate aerosol-cloud interaction. J. Geophys. Res. 113, D15211. http://dx.doi.org/10.1029/2007JD009361.

Li, Z., Niu, F., Fan, J., Liu, Y., Rosenfeld, D., Ding, Y., 2011. Long-term impacts of aerosols on the vertical development of clouds and precipitation. Nature Geosci. 4 (12), 888-894. http://dx.doi.org/10.1038/ngeo1313.

Lohmann, U., Lesins, G., 2002. Stronger constraints on the anthropogenic indirect aerosol effect. Science 298 (5595), 1012-1015. http://dx.doi.org/10.1126/science.1075405.

Ludlam, F. H., 1980. Clouds and Storms. Penn State Univ. Press, University Park, PA.

Menon, S., Genio, A. D. D., Koch, D., Tselioudis, G., 2002. GCM simulations of the aerosol indirect effect: Sensitivity to cloud parameterization and aerosol burden. J. Atmos. Sci. 59 (3), 692-713.

Mülmenstädt, J., Sourdeval, O., Delanoë, J., Quaas, J., 2015. Frequency of occurrence of rain from liquid-, mixed-, and ice-phase clouds derived from A-Train satellite retrievals. Geophys. Res. Lett. 42 (15), 6502-6509. http://dx.doi.org/10.1002/2015GL064604. 
Mlawer, E. J., Taubman, S. J., Brown, P. D., Iacono, M. J., Clough, S. A., 1997. Radiative transfer for inhomogeneous atmospheres: RRTM, a validated correlated-k model for the longwave. J. Geophys. Res. 102 (D14), $16663-16682$.

Murray, B. J., O’Sullivan, D., Atkinson, J. D., Webb, M. E., 2012. Ice nucleation by particles immersed in supercooled cloud droplets. Chem. Soc. Rev. 41 (19), 6519.

Phillips, V. T. J., DeMott, P. J., Andronache, C., 2008. An empirical parameterization of heterogeneous ice nucleation for multiple chemical species of aerosol. J. Atmos. Sci. 65 (9), 2757-2783. http://dx.doi.org/10.1175/2007JAS2546.1.

Platnick, S., Twomey, S., 1994. Remote sensing the susceptibility of cloud albedo to changes in drop concentration. Atmos. Res. 34 (1), 85-98.

Pruppacher, H. R., Klett, J. D., 1997. Microphysics of Clouds and Precipitation, 2nd ed., 914 pp. Oxford Press, Oxford.

Qian, Y., Gong, D., Fan, J., Leung, L. R., Bennartz, R., Chen, D., Wang, W., 2009. Heavy pollution suppresses light rain in China: Observations and modeling. J Geophys. Res. 114, D00K02. http://dx.doi.org/10.1029/2008JD011575.

Quaas, J., Boucher, O., Bréon, F. ., 2004. Aerosol indirect effects in POLDER satellite data and the Laboratoire de Météorologie DynamiqueZoom (LMDZ) general circulation model. J. Geophys. Res. 109, D08205. http://dx.doi.org/10.1029/2003JD004317. 
Rosenfeld, D., 1999. TRMM observed first direct evidence of smoke from forest fires inhibiting rainfall. Geophys. Res. Lett. 26 (20), 3105.

Rosenfeld, D., 2006. Aerosol-cloud interactions control of earth radiation and latent heat release budgets. Space Sci. Rev. 125, 149-157. http://dx.doi.org/10.1007/s11214-006-9053-6.

Rosenfeld, D., Lensky, I. M., 1998. Satellite-based insights into precipitation formation processes in continental and maritime convective clouds. Bull. Amer. Meteorol. Soc. 79 (11), 2457-2476.

Rosenfeld, D., Rudich, Y., Lahav, R., 2001. Desert dust suppressing precipitation: A possible desertification feedback loop. Proc. Natl. Acad. Sci. USA 98 (11), 5975-5980. http://dx.doi.org/10.1073/pnas.101122798.

Rosenfeld, D., Woodley, W. L., 2000. Deep convective clouds with sustained supercooled liquid water down to $-37.5^{\circ}$ C. Nature 405, 440-442. http://dx.doi.org/10.1038/35013030.

Saleeby, S. M., Herbener, S. R., van den Heever, S. C., 2015. Impacts of cloud droplet-nucleating aerosols on shallow tropical convection. J. Atmos. Sci. $72(4), 1369$.

Seifert, A., Beheng, K. D., 2006. A two-moment cloud microphysics parameterization for mixed-phase clouds. Part 1: Model description. Meteorol. Atmos. Phys. 92 (1), 45-66.

Sekiguchi, M., Nakajima, T., Suzuki, K., Kawamoto, K., Higurashi, A., Rosenfeld, D., Sano, I., Mukai, S., 2003. A study of the direct and indirect effects of aerosols using global satellite data sets 
of aerosol and cloud parameters. J. Geophys. Res. 108 (D22), 4699. http://dx.doi.org/10.1029/2002JD003359.

Stefan, S., Iorga, G., 18-23 July 2004. Effects of aerosol on the optical properties of clouds. In: Proceedings of the 14th International Conference on Clouds and Precipitation. Bologna, Italy.

Storer, R. L., van den Heever, S. C., Stephens, G. L., 2010. Modeling aerosol impacts on convective storms in different environments. J. Atmos. Sci. 67 (12), 3904-3915.

Teller, A., Levin, Z., 2006. The effects of aerosols on precipitation and dimensions of subtropical clouds: a sensitivity study using a numerical cloud model. Atmos. Chemis. Phys. 6 (1), 67-80.

Thompson, G., Eidhammer, T., 2014. A study of aerosol impacts on clouds and precipitation development in a large winter cyclone. J. Atmos. Sci. $71(10), 3636-3658$.

Thompson, G., Field, P. R., Rasmussen, R. M., Hall, W. D., 2008. Explicit forecasts of winter precipitation using an improved bulk microphysics scheme. Part II: Implementation of a new snow parameterization. Mon. Weather Rev. 136 (12), 5095-5115.

Twomey, S., 1977. The influence of pollution on the shortwave albedo of clouds. J. Atmos. Sci. 34 (7), 1149-1152.

Twomey, S. A., Piepgrass, M., Wolfe, T. L., 1984. An assessment of the impact of pollution on global cloud albedo. Tellus B 36B (5), 356-366. 
${ }_{733}$ Wang, Y., 2015. Aerosol-Cloud Interactions from Urban, Regional, to Global, 73486 pp. Springer.

Zhang, J., Lohmann, U., Stier, P., 2005. A microphysical parameterization for convective clouds in the ECHAM5 climate model: Singlecolumn model results evaluated at the Oklahoma Atmospheric Radiation Measurement Program site. J. Geophys. Res. 110, D15S07. http://dx.doi.org/10.1029/2004JD005128.

Zhang, S., Wang, M., Ghan, S. J., Ding, A., Wang, H., Zhang, K., Neubauer, D., Lohmann, U., Ferrachat, S., Takeamura, T., Gettelman, A., Morrison, H., Lee, Y. H., Shindell, D. T., Partridge, D. G., Stier, P., Kipling, Z., Fu, C., 2015. On the characteristics of aerosol indirect effect based on dynamic regimes in global climate models. Atmos. Chem. Phys. Discuss. $15,23683-23729$. 
Table 1. The innermost domain-averaged hygroscopic aerosol number concentration $\left(\mathrm{cm}^{-3}\right)$ averaged over the simulation period and in all vertical levels, as well as the innermost domain-averaged number concentration $\left(\mathrm{cm}^{-3}\right)$ and effective radius of cloud droplets $(\mu \mathrm{m})$ in cloudy grid points averaged over the simulation period. The accumulated rainfall (mm) for the simulation period, from 0000 UTC 14 April to 0000 UTC 15 April 2012, for the clean, control and polluted experiments are also provided.

\begin{tabular}{lcccc}
\hline Experiments & $\begin{array}{c}\text { Mean hygroscopic aerosol } \\
\text { number concentration }\left(\mathrm{cm}^{-3}\right)\end{array}$ & $\begin{array}{c}\text { Mean cloud droplet number } \\
\text { concentration }\left(\mathrm{cm}^{-3}\right)\end{array}$ & $\begin{array}{c}\text { Mean effective radius } \\
\text { of cloud droplets }(\mu \mathrm{m})\end{array}$ & $\begin{array}{c}\text { Accumulated } \\
\text { rain }(\mathrm{mm})\end{array}$ \\
\hline Clean & 105.5 & 45.9 & 8.53 & 13.3 \\
Control & 574.7 & 158.3 & 6.10 & 12.7 \\
Polluted & 2670.8 & 416.5 & 5.22 & 13.1 \\
\hline
\end{tabular}

Table 2. The innermost domain-averaged shortwave and longwave cloud forcing (SWCF and LWCF, $\mathrm{W} \mathrm{m}^{-2}$ ) at the top of the atmosphere (TOA), lifting condensation level (LCL) or cloud base $(\mathrm{m})$ and liquid water content $\left(\mathrm{LWC}, \mathrm{mg} \mathrm{m}^{-3}\right.$ ) at cloud base averaged over the simulation period from 0000 UTC 14 April to 0000 UTC 15 April 2012 for the control, clean and polluted experiments.

\begin{tabular}{lcccc}
\hline Experiments & $\mathrm{SWCF}\left(\mathrm{W} \mathrm{m}^{-2}\right)$ & $\mathrm{LWCF}\left(\mathrm{W} \mathrm{m} \mathrm{m}^{-2}\right)$ & $\mathrm{LCL}(\mathrm{m})$ & $\mathrm{LWC}\left(\mathrm{mg} \mathrm{m}^{-3}\right)$ \\
\hline Clean & -94.8 & 50.7 & 1710.7 & 16.56 \\
Control & -105.9 & 49.9 & 1745.9 & 16.83 \\
Polluted & -111.0 & 50.3 & 1773.3 & 18.08 \\
\hline
\end{tabular}




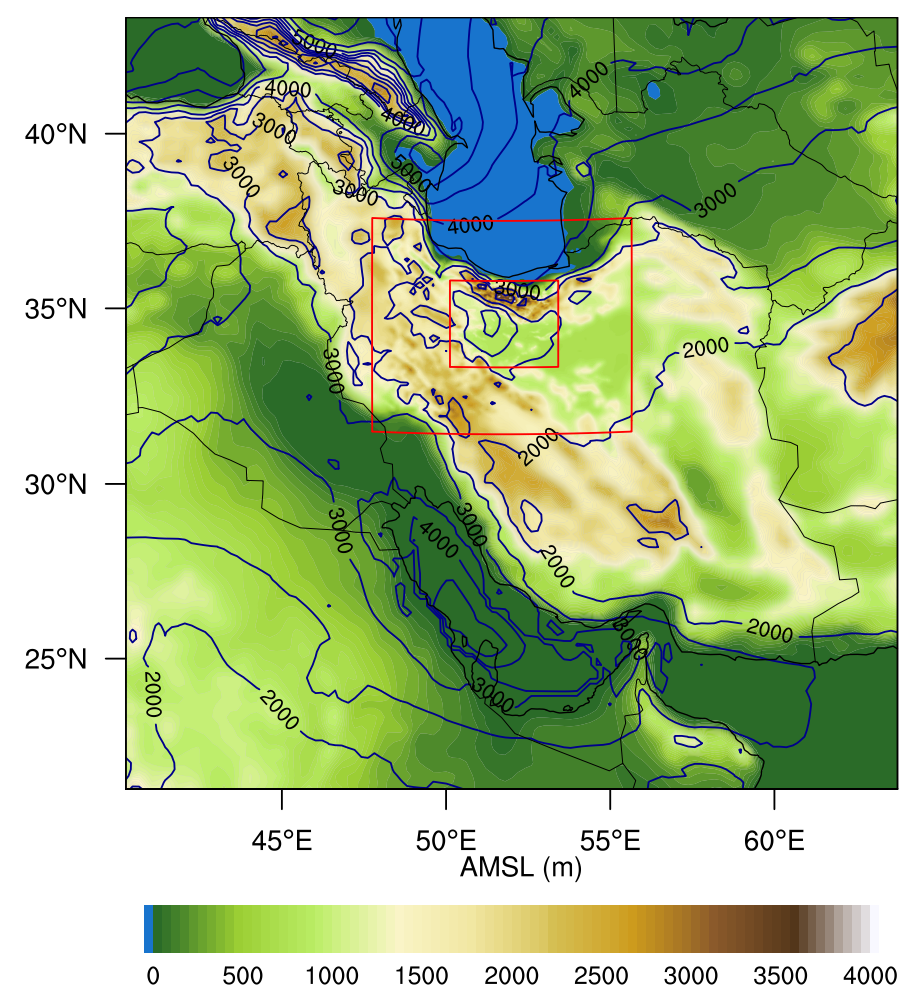

Figure 1. Multiple-nested model configuration of the three sensitivity experiments, with the grid spacing of 21000, 7000 and $2333 \mathrm{~m}$ for the mother and two nested domains, respectively. The initial hygroscopic aerosol number concentration (blue contours, $\mathrm{cm}^{-3}$ ) at the surface in the control simulation and topographical features (shaded, m) are overlapped. The color bar indicates elevation above the mean sea level (AMSL). 

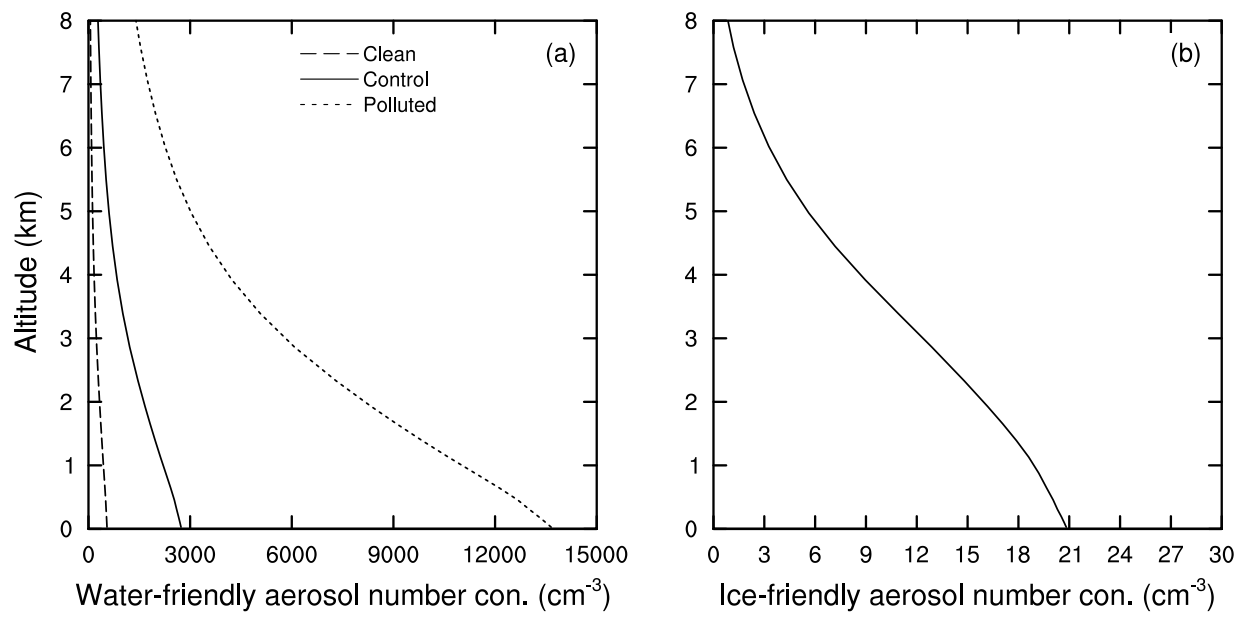

Figure 2. The initial vertical profiles of (a) hygroscopic aerosol number concentration $\left(\mathrm{cm}^{-3}\right)$ and (b) ice-friendly aerosol number concentration $\left(\mathrm{cm}^{-3}\right)$ averaged over the innermost domain for the clean, control and polluted experiments. Note that the initial ice-friendly aerosol number concentration is identical for the three experiments. 

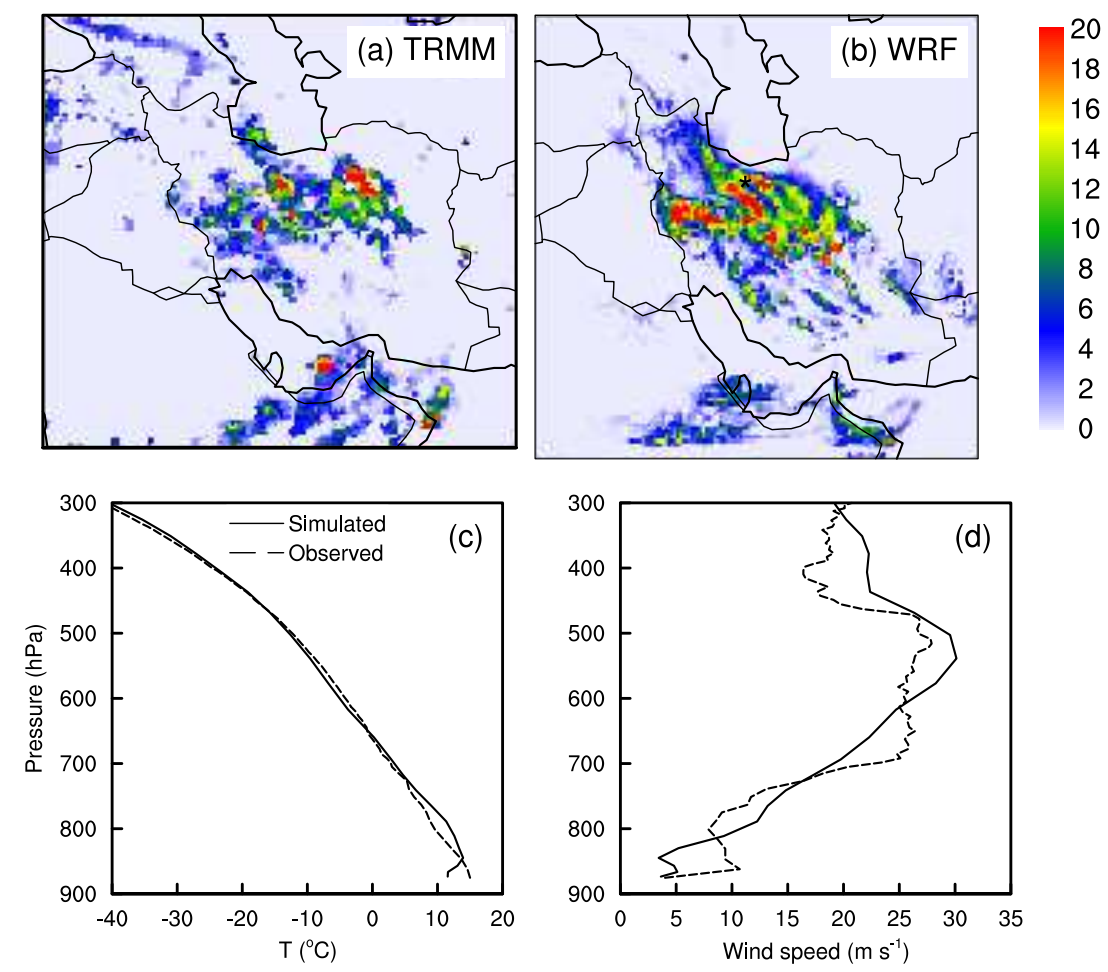

Figure 3. Accumulated rainfall from 0000 to 2100 UTC 14 April 2012 a) observed by the Tropical Rainfall Measuring Mission (TRMM) satellite and b) simulated by the Weather Research and Forecasting (WRF) model in the mother domain, and profiles of c) air temperature $\left({ }^{\circ} \mathrm{C}\right)$ and $(\mathrm{d})$ wind speed $\left(\mathrm{m} \mathrm{s}^{-1}\right)$ at 0000 UTC 14 April 2012 observed by a radiosonde (dashed lines) and simulated by the control experiment of the innermost 


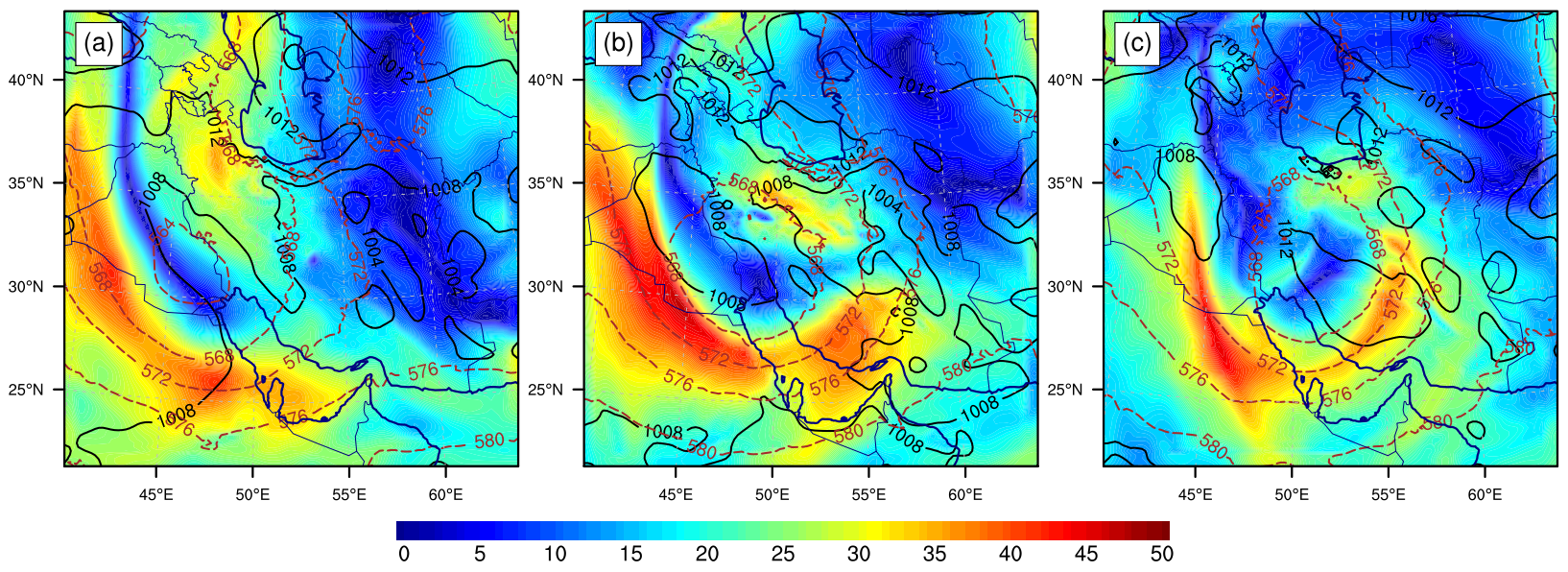

Figure 4. Mean sea level pressure (solid black contour, contour interval $4 \mathrm{hPa}$ ), geopotential height at $500 \mathrm{hPa}$ (dashed brown contour, contour interval $4 \mathrm{dm}$ ) and wind speed at $300 \mathrm{hPa}$ (shaded, $\mathrm{m} \mathrm{s}^{-1}$ ) in the mother domain at (a) 0000 UTC 14 April (b) 1200 UTC 14 April and (c) 0000 UTC 15 April 2012. 

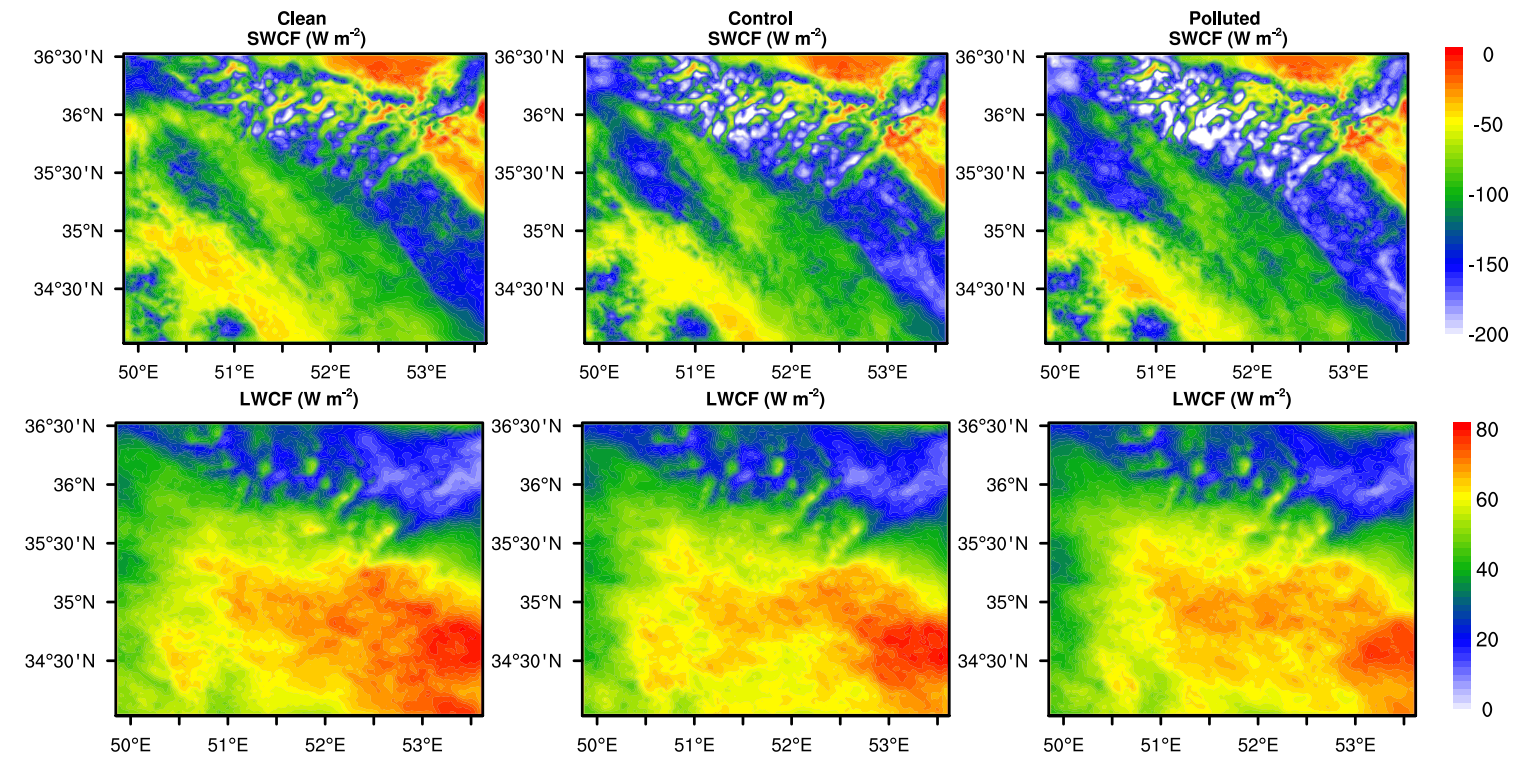

Figure 5. Shortwave (top, $\mathrm{W} \mathrm{m}^{-2}$ ) and longwave (bottom, $\mathrm{W} \mathrm{m}^{-2}$ ) cloud forcing at the top of the atmosphere (TOA) in the innermost domain averaged over the simulation period for the clean (left), control (middle) and polluted (right) experiments. 

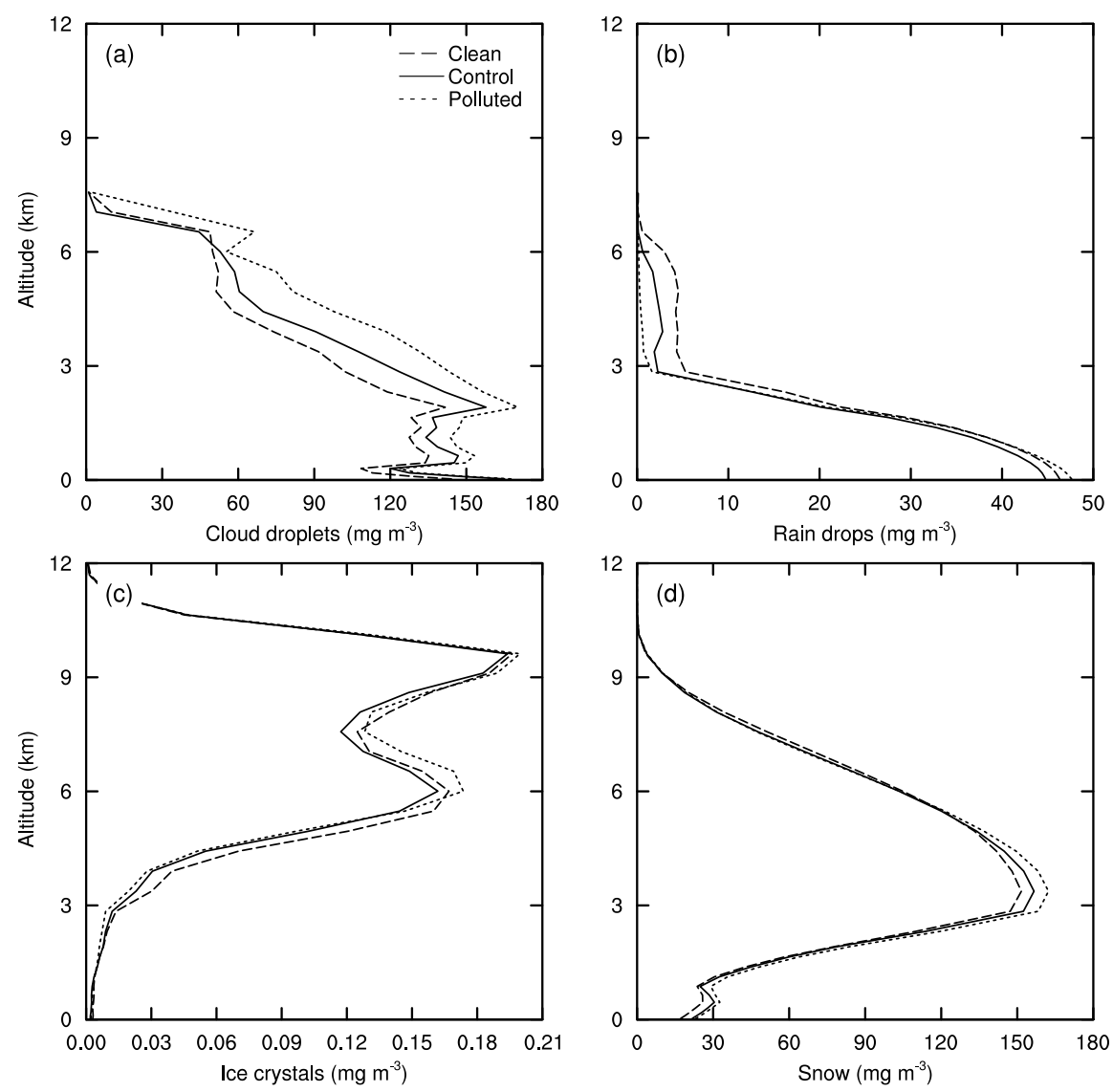

Figure 6. Vertical profiles of (a) cloud droplets, (b) rain drops, (c) ice crystals and (d) snow contents in $\mathrm{mg} \mathrm{m}^{-3}$ averaged during the simulation period for the clean, control and polluted experiments. Averages were taken over grid points of the innermost domain with nonzero values. 

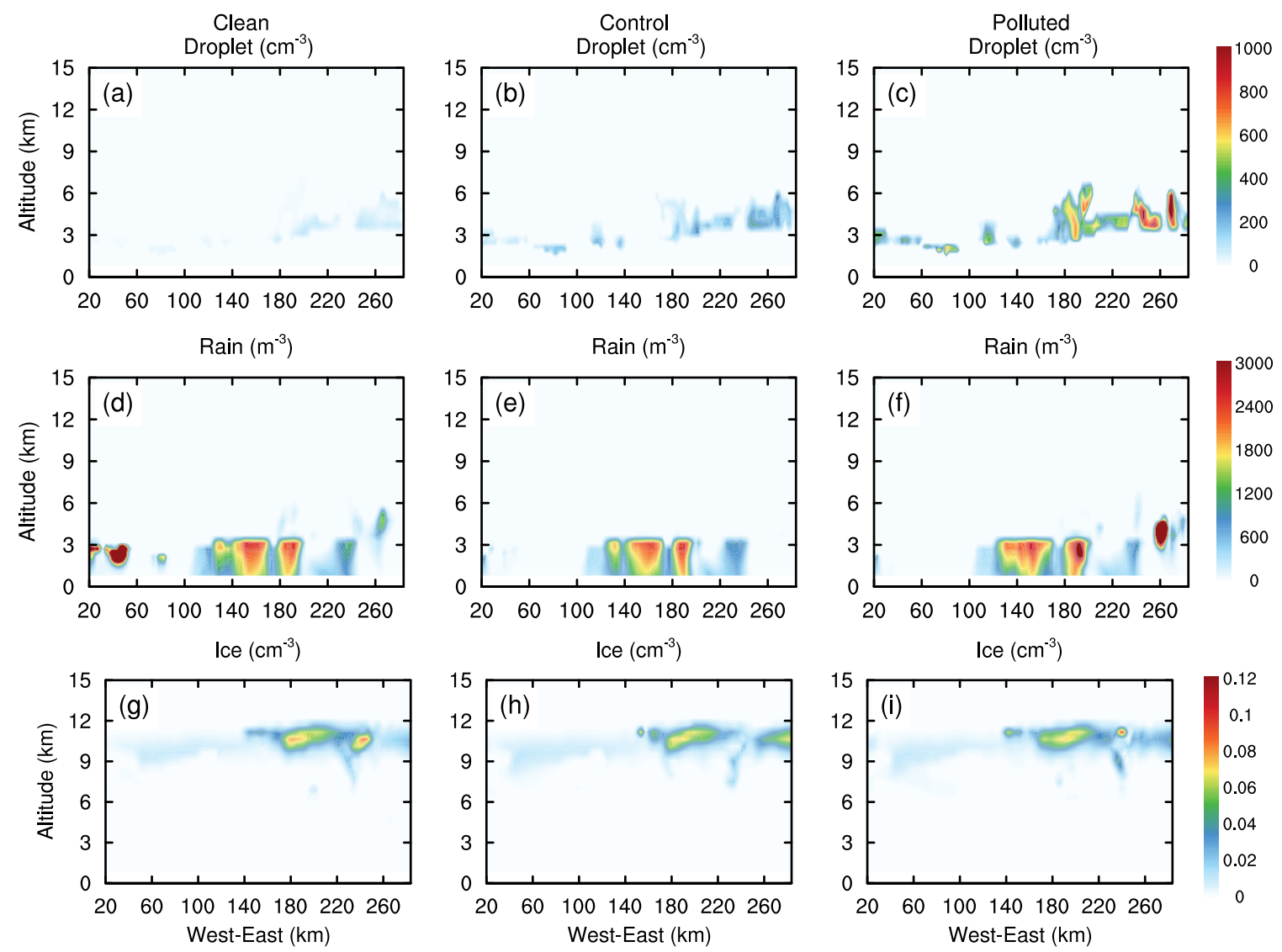

Figure 7. Vertical cross sections of the number concentration of cloud droplets, rain drops and ice particles in $\mathrm{cm}^{-3}$ for the clean (left), control (middle) and polluted (right) experiments in the innermost domain at around $35^{\circ} \mathrm{N}$ at 0400 UTC 14 April 2012. 

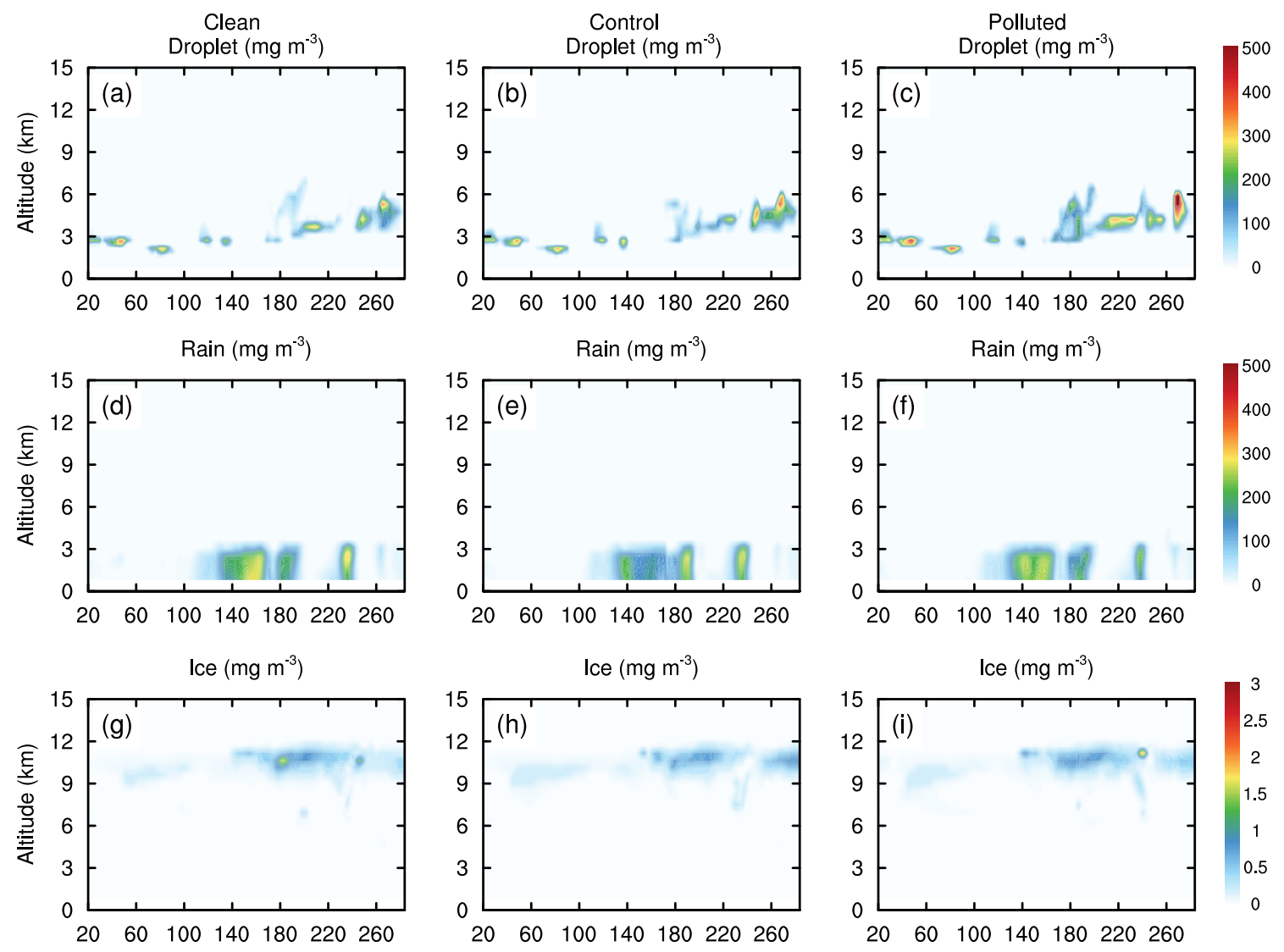

Figure 8. As in Figure 7, but for the mass concentration in $\mathrm{mg} \mathrm{m}^{-3}$. 

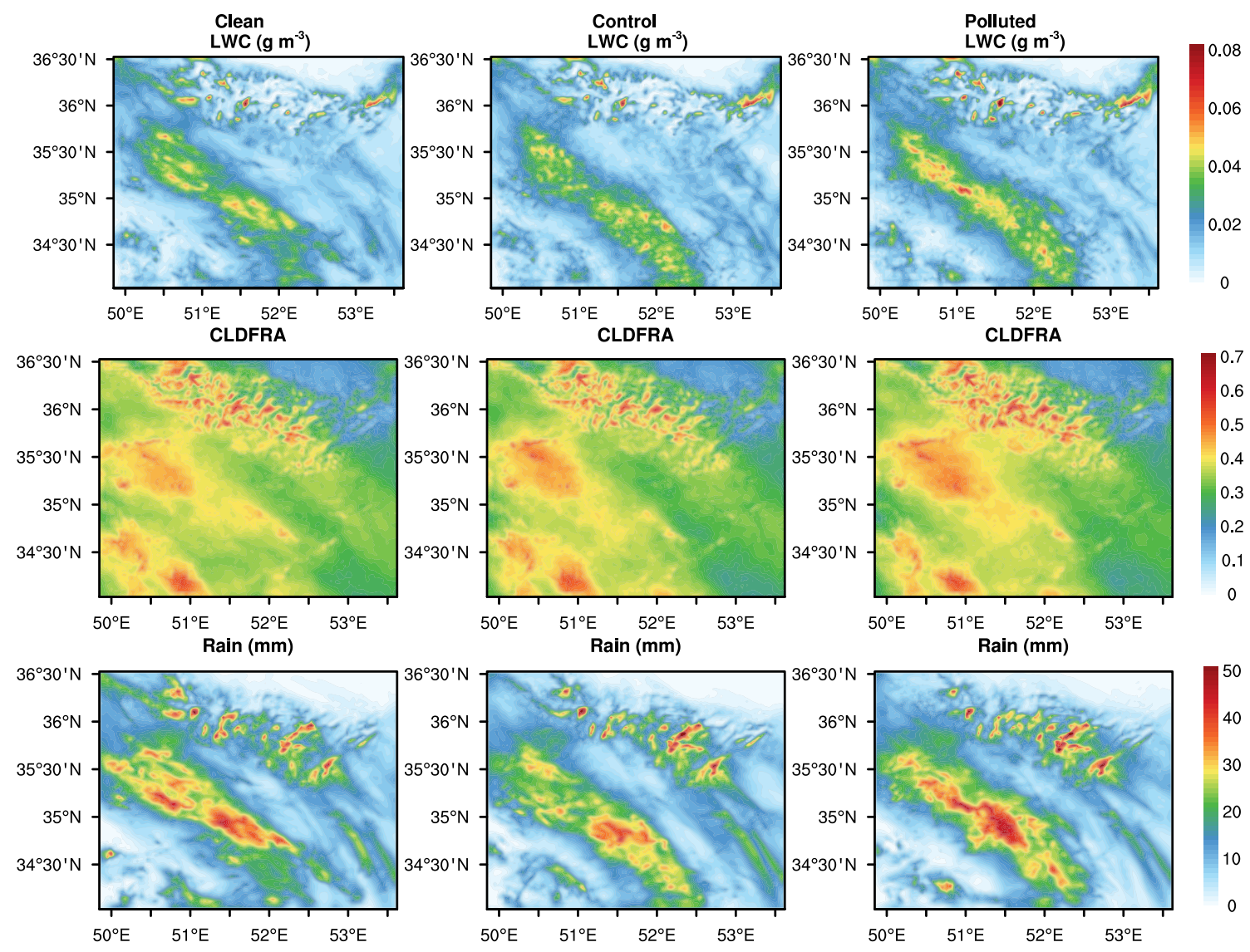

Figure 9. The liquid water content $\left(\mathrm{g} \mathrm{m}^{-3}\right)$ and cloud fraction (CLDFRA) averaged over the simulation period, as well as accumulated rainfall in the innermost domain from 0000 UTC 14 April to 0000 UTC 15 April 2012 in the clean (left), control (middle) and polluted (right) experiments. 


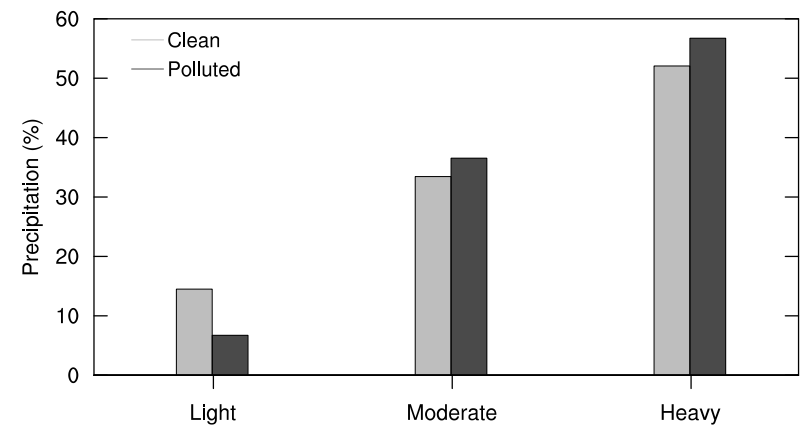

Figure 10. Probability distribution functions of three different precipitation categories under the clean and polluted experiments. Hourly rates of precipitation from 0000 UTC 14 April to 0000 UTC 15 April 2012 were computed through averaging over the innermost domain. The hourly precipitation values then were categorized into three classes based on the intensity, which include light $\left(<0.6 \mathrm{~mm} \mathrm{hr}^{-1}\right)$, moderate $\left(0.6-1 \mathrm{~mm} \mathrm{hr}^{-1}\right)$ and heavy $\left(>=1 \mathrm{~mm} \mathrm{hr}^{-1}\right)$. Values are percentage of precipitation amount under the three categories over the total precipitation amount. 